That libraries are Wartime Activities giving generously of their facilities to the war effort is apparent in the reports that have been received. Accelerated programs are already in operation in many institutions making necessary adjustments of personnel and book budgets. Key centers of information and training have been set up in 140 colleges and universities and the libraries of most of these institutions are sponsoring war information libraries. Libraries in institutions not key centers likewise are establishing offices for the dissemination of war information to faculty and students. Faculty members and their wives are lending their services to these information centers. Booklets and bibliographies describing the new services are being distributed and in many institutions package libraries are provided for state-wide distribution. In at least one urban community a wartime council, which includes all of the libraries of the area, has been formed and a union checklist made of the materials in the cooperating libraries which might be of special value to industry or to civilian groups. Plans for the conservation of materials and the safeguarding of staff have been worked out in inland and coastal institutions and in some instances on a state-wide basis.

East

A regional library conference which includes the states of

New Jersey, Pennsylvania, Delaware, Maryland, West Virginia, and the District of Columbia will be held at the Inn, Buck Hill Falls, Pennsylvania, on October 22-24. The theme will be "The Library in a War Economy." Charles W. Mixer,

\section{News from}

librarian of the United States Naval Academy, Annapolis, is chairman of the Program Committee.

Bard College Library, Felix E. Hirsch, librarian, has been completely modernized. The building has been redecorated, fluorescent lighting and oil heating introduced. The basement has been rebuilt; a large study hall, a library office, and the Bardiana Room for special collections have been added, and stack space sufficient for a considerable number of years provided.

The philosophy collection of the late Professor David W. Prall of Harvard University, established as a memorial to him by his sister, Margaret C. Prall, has recently been received at Queens College Library, Flushing, N.Y., according to Charles F. Gosnell, librarian. The collection comprises some fifteen hundred volumes, including works of the leading Greek, Roman, French, German, British, and American philosophers. As its graduation gift to the college, the senior class of February 1942 has given the library a fund of two hundred and fifty dollars for adding current material to the collection.

All libraries administered by agencies of the Department of Agriculture and all units of the department providing library and bibliographical service were consolidated by Executive Order 9069, dated February 23, 1942.

To expedite an institution-wide faculty study of the University of New Hampshire's program and procedures, a faculty workshop has been organized in the library and two faculty members have been appointed to serve in the capacity of reference librarians. 


\section{the Field}

The Philadelphia Bibliographical Center and Union Library Catalog has announced through its Committee on Microphotography the publication of a Union List of Microfilms, A Basic List of Holdings in the United States and Canada. The list, which comprises more than five thousand items, represents holdings of over IoO institutions. Copies of the list may be purchased through the Center, Fine Arts Building, University of Pennsylvania, Philadelphia. Cost $\$ 4.00$.

West

The Committee on Bibliography of the Pacific North-

west Library Association is supervising a survey of library resources in the states of Idaho, Montana, Oregon, and Washington and the province of British Columbia. The librarians of each library are listing and evaluating their resources. John Van Male, on leave from the Denver Bibliographical Center, is to conduct the field work and compile the results. This survey which has been under contemplation for some years as a basis for future regional planning and as a means of coordinating library specialization and of avoiding duplication, has been undertaken sooner than was originally intended because of the present war emergency and the need for a complete mobilization of regional library resources. The survey is being financed by the Pacific Northwest Bibliographic Center.

A meeting on library cooperation was sponsored at the University of Utah on March 2 by Herbert A. Kellar of the Library of Congress. Practically all of the libraries of that area were represented.

The Library Association of Portland Library, Nell A. Unger, librarian, is to receive the income from a fund established in memory of the former United States Senator, Jonathan Bourne of Oregon, by his sister, Emily Howland Bourne. The income will be used to purchase materials on the Pacific Northwest and related subjects.

The summer session at Mills College will feature a casa Pan Americana for the special study of Latin American affairs, under the direction of Samuel I. Inman. The library is preparing a collection of books for the Pan Americana house, in which the students will live along with the Latin American instructors and scholars.

\section{Middle West}

A new library for St. Olaf College, Northfield, Minn., is near completion, according to Alf Houkom, librarian. The college alumni group, of less than five thousand members, contributed practically all of the building cost of $\$ 310,000$. The building is arranged so that for the present it will include also a student recreation room, post office, book store, and a few classrooms. The library may later expand into the quarters now occupied by these nonlibrary activities with a minimum of interior alterations. There will be seven stack levels with a book capacity of about two hundred thousand volumes.

Downing P. O'Harra, librarian of the Municipal University of Wichita, Wichita, Kan., is making a survey of the reading done by students in that institution during the school year 1940-4I. His study will attempt to show the average 
number of books drawn per student, the number each student borrowed, and the relationship between course grades and the students' use of the library.

Kansas colleges and universities, including the five state institutions, are offering courses in library science this summer. These courses are designed to meet the new requirements of the state department of education, which stipulate that teacher librarians in class $A$ high schools must have at least eight semester hours of college instruction in this field.

A new building has been erected at Carroll College, Waukesha, Wis., Hanna E. Kruger, acting librarian. It will have a stack capacity of forty-five thousand volumes and will seat 40 per cent of the student body. It was completed in March I 942.

\section{Southwest}

A joint meeting of the Southwestern and Southeastern Library Associations will be held in New Orleans in October. Latin American studies will be stressed.

Representatives of five of the New Mexico colleges and universities are preparing plans for a uniform curricula of library science instruction in these institutions. By offering the same preparation to teacher librarians they hope to contribute to the standardization of highschool libraries in the state.

The Kentucky LiSouth brary Association is one of the most recent associations to organize a college and reference library section. The organization was formally completed in October I94 I. Margaret I. King, librarian, University of Kentucky, was elected chairman, and Virginia Winstanley, University of
Louisville, was elected cochairman.

The University of Louisville will share in a trust fund set up in the will of the late Justice Louis D. Brandeis. Justice Brandeis was for many years a benefactor of the university and during his lifetime presented to the library all of his personal papers and correspondence. Evelyn J. Schneider is librarian.

The Bryan Collection, which has been on deposit for several years at the University of North Carolina Library, Charles E. Rush, librarian, has been given to the university by Colonel Charles S. Bryan. The collection comprises about eighteen hundred volumes. It is noted chiefly for its material on the Confederacy, local North Carolina history, and for its long runs of early Newbern, N.C., newspapers. It is established as a memorial to Colonel. Bryan's grandfather, James West Bryan.

The maintenance of a liberal interlibrary loan service at Duke University and the University of North Carolina enables the two institutions to render valuable assistance to research workers at other schools in the region. As an indication of its interest in this program the Carnegie Corporation has recently granted the two universities for an experimental period a limited fund which will enable them to purchase books of a specialized character not already in the collections but needed for research.

The Woman's College of the University of North Carolina, Guy R. Lyle, librarian, has issued a thirty-page handbook called Using the Library. A Faculty Handbook. It contains a directory of the library staff and faculty library committee, a floor plan of the library, information about circulation, reference, and reserve room practices, the card catalog, interlibrary services, and other information use- 
ful to the faculty. Copies may be secured on loan from A.L.A. Headquarters $\mathrm{Li}$ brary.

The University of Florida Library, Walter B. Hill, librarian, is now using the International Business Machines in its order and circulation departments. The new $\$ 70,000$ law library of the university was dedicated on November 21 with appropriate ceremonies.

The Florida State College for Women, Louise Richardson, librarian, has recently completed two additional stack floors, which will approximately double the shelving space of the library.

\section{Personnel}

Ralph A. Beals, assistant librarian, Public Library of

the District of Columbia, Washington, D.C., has been appointed director of libraries of the University of Chicago and professor of library science in the Graduate Library School. He will succeed $\mathbf{M}$. Llewelyn Raney, who will retire on October I, after fifteen years of service as director of libraries.

Carleton Bruns Joeckel, professor in the Graduate Library School, University of Chicago, since 1935, has been appointed dean of that school. He will succeed Louis Round Wilson, who retires October I. Dr. Wilson has been dean of the Graduate Library School since 1932.

James M. Kingsley, Jr., assistant librarian at Cooper Union, has been appointed assistant to Harry Miller Lydenberg in the operation of the Biblioteca Benjamin Franklin recently opened in Mexico City. The library, similar to the American Library in Paris, will provide American books, periodicals, pamphlets, and other educational and informative materials for the use of those interested in the cultural, social, industrial, and governmental activities of the United States.

Herman H. Henkle was appointed director of the Processing Department of the Library of Congress, effective February I. He succeeded L. Quincy Mumford, who returned to the New York Public Library after a year's leave of absence spent in organizing the department. Henkle went to the Library of Congress from Simmons College, Boston, where he was professor of library science and director of the School of Library Science.

Amelia Kreig, who resigned recently as assistant director of the University of Illinois Library School, is now head of the cataloging department of the Seattle Public Library.

Clara Mackauer, formerly librarian of the Institute for Social Research, University of Frankfurt, Germany, has been appointed librarian of the Pacific College Library, Newberg, Ore.

Zaidee Brown retired in August 194I as librarian of Rutgers University Library. She was succeeded by Margaret G. Cook, assistant librarian.

Fulmer Mood's name was misspelled Wood in the September 194I instalment of News from the Field, where his appointment to an assistant professorship in the School of Librarianship, University of California, was announced.

Edith M. Brainard, president of the Kansas Library Association and librarian of Southwestern College, Winfield, Kan., has resigned her position to become librarian of the Itasca Junior College, Coleraine, Minn. Helen A. Dooley has been appointed to the Southwestern position and Julia McCarty, vice-president of the association, has succeeded to the presidency.

Benjamin E. Powell 


\section{In Anticipation of Reconstruction}

\section{(Continued from page 206)}

By the end of 1942 the Association will own a supply of I 939-42 issues of many of the most important research journals. The committee assumes that the supply will be adequate to cope with the requests from at least the outstanding foreign research centers and that European and Asiatic scholarship therefore will not be entirely deprived of the product of American research during the war years.

\section{Augmenting Purchased Supply}

The committee would like to be able to accomplish more than this and has realized from the first the necessity for augmenting the purchased supply of journals with an active campaign for gifts. The lack of large-scale storage space has made the postponement of such a campaign seem wise. In the meantime the committee is doing everything it can to insure the success of this future campaign.

The supply of learned journals is never large and even under normal conditions tends to disappear rapidly. With today's abnormal demand for material for pulp this supply will be rapidly absorbed unless definite steps are taken to protect it. The December issue of this journal carried, as did other library periodicals, a brief statement of the aims of the committee in the preservation of scholarly journals. Many of the journals themselves are currently printing a similar statement in an attempt to notify individual scholars. These statements have brought forth offers and promises of gifts and have undoubtedly prevented some destruction of the supply. The committee feels that the institutions and individuals represented in the Association of College and Reference Libraries are the logical source of further assistance.

Though a large-scale campaign isn't yet possible small campaigns can be accomplished and will contribute greatly to the success of the final program. At least in one instance a local campaign is already in progress. Flora B. Ludington, the librarian of Mount Holyoke College, has reported such a campaign and its success should encourage librarians of other institutions. A brief statement of the problem in faculty meeting, supported by personal appeals to individual faculty members, will bring offers and promises of current journals. A letter to the emeritus members of the teaching staff will make available another supply. The library duplicate collection can be combed with the committee's interest in mind, setting aside odd numbers or complete volumes of the important American journals.

The committee will be grateful for any activity of this nature, sure that it is attracting and protecting a quantity of important research material that would no longer be available for collection in even a year or two. A list of some four hundred journals, judged to be those for which the committee will receive the most requests, has been prepared. Requests for this list, questions concerning the project, and reports of cooperative activity should be directed to Wayne M. Hartwell, Executive Assistant to the Committee on Aid to Libraries in War Areas, Rush Rhees Library, University of Rochester, Rochester, N.Y. 


\section{MINUTES OF THE MEETING OF THE BOARD OF DIRECTORS OF A.C.R.L., CHICAGO, DECEMBER 28, I94I}

A meeting of the Board of Directors of the Association of College and Reference Libraries was called to order at 8:00 P.M., December 28, 194I, at the Drake Hotel, Chicago. The directors present were President Donald Coney, Vice President Mabel L. Conat, Secretary Benjamin E. Powell, A.C.R.L. Directors Etheldred Abbot and Winifred Ver Nooy; Section Directors: Fina C. Ott of College Libraries Section; Lois E. Engleman, Junior College Libraries Section; and Mary Floyd, Librarians of Teacher-Training Institutions Section. Section chairmen present were Eugene $\mathrm{H}$. Wilson, Agricultural Libraries; Anna M. Tarr, College Libraries; Maysel O'H. Baker, Junior College Libraries; Charles V. Park, Libraries of Teacher-Training Institutions; Fanny A. Coldren, Reference Librarians. Others present by invitation were Louis Shores, chairman, A.C.R.L. Committee on Budget, Compensation, and Schemes of Service; Ralph E. Ellsworth, chairman, A.C.R.L. Committee on College and University Library Buildings; Samuel W. McAllister, chairman, A.C.R.L. Committee on Constitution and By-Laws; Thomas P. Fleming, A.L.A. Committee on Importations; Charles H. Brown, chairman, A.C.R.L. Committee to Apply to Certain Institutions a "Study of the Use of Books in the Different Courses in the College Curricula;" Charles M. Mohrhardt, chairman, A.C.R.L. Special Committee on National Defense Services; Carl M. White, editor, College and $R e$ search Libraries; E. W. McDiarmid, associate editor, College and Research Libraries.

In view of publication in the September I94I issue of College and Research Libraries, the minutes of the last meeting were approved as published.

Ralph E. Ellsworth presented a brief report on the proposed work of the A.C.R.L. Committee on College and University Library Buildings.
Thomas P. Fleming, of the A.L.A. Committee on Importations, reported that his committee has been concerned (I) with the status of 1942 subscriptions to foreign periodicals and especially with efforts to secure permission from the State Department and Great Britain for the acquisition by American research libraries of essential scientific and technical journals; and (2) the release of books and journals now held in Bermuda by the British.

The activities of the A.C.R.L. Special Committee on National Defense Services were summarized by the chairman, Charles M. Mohrhardt. An earlier report of the work of this committee appeared in the December 1941 College and Research $\mathrm{Li}_{-}$ braries.

The report of the Committee on Budget, Compensation, and Schemes of Service was presented by Chairman Louis Shores. After considerable discussion, it was

VOTED to accept the evaluative section of the report and defer acceptance of the score card. The importance of regarding the committee's report as a suggestion for self-evaluation rather than as a device for accrediting libraries was stressed.

Chairman Brown of the Committee to Apply to Certain Institutions a "Study of the Use of Books in the Different Courses of the College Curricula" reported that he expects to resume work after June. It was

VOTED that the committee be continued but be permitted to remain dormant until the expiration of the chairman's term as President of the American Library Association.

Carl M. White, editor of College and Research Libraries, presented a mimeographed report which called for board study and advice relative to the future policy of the journal. The questions in point were whether the journal should be edited as a 
journal of discussion or of review-review here being interpreted as a medium for the publication of lists of serials, documents, reference books, and other review articles. After considerable discussion, it was VOTED that the journal be continued primarily as a journal of discussion.

It was also VOTED that within the next year the mittee to Consider with a Joint Committee from the American Association for Health, Physical Education, and Recreation the Project for the Publication of an Encyclopaedia of Sports and Games. It was VOTED to continue the committee and to allocate the funds necessary for the continuation of the project during the next several months.

\section{Treasurer's RePORT}

Balance Jan. I, I94I

Allotment from A.L.A.

Additional section choices

Totals

College and Research Libraries

Subsidy

Contingent

Sectional expenses

College section

Junior College section

Reference Librarians section

Teacher Training section

General promotion

Committee expenses

Jt. Committee on Ency. of Sports

Committee on Budget, etc.

Other committee activity

Officers' expenses

Secretary

Special travel

Treasurer

Totals

Balance on hand December I94I

\section{Income}

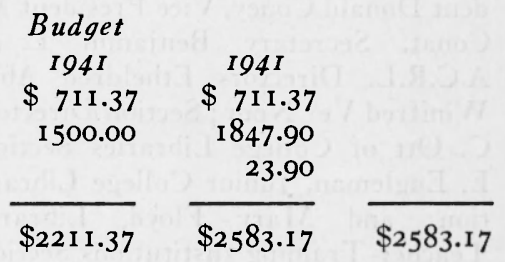

Expenditures

$\begin{array}{cc}\$(500.00) & \$(500.00) \\ 250.00 & 250.00 \\ 250.00 & 250.00 \\ (500.00) & (200.25) \\ & 40.00 \\ & 33.05 \\ & 50.00 \\ & 77.20\end{array}$

(200.00)

( $100.8 \mathrm{I})$

50.00

25.81

75.00

75.00

(300.00)

75.00

100.00

(249.42)

124.24

85.58

200.00

39.60

$\$ 1600.00$

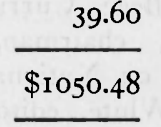

editors should send the readers of $\mathrm{Col}$ lege and Research Libraries a questionnaire designed to determine the reader interest of the various sections of the journal.

The Secretary read the report of the chairman (Wilson M. Ranck) of the Com-
The Treasurer was not present but submitted the above report for 1941.

Attention was next turned to the 1942 budget. The President called attention to the cash balance of $\$ 1532.69$ as reported by the Treasurer. After some deliberation, in which votes on major items were called for, 
it was

VOTED to approve the budget for 1942 as outlined below:

Income $\quad \begin{gathered}1942 \\ \text { Budget }\end{gathered}$

Balance Jan. I ............. \$I 532.69

Allotment from A.L.A. ........ I 1500.00

Additional section choices ....... 25.00

Total .............\$3057.69

\section{Expenditures}

College and Research Libraries..\$800.00 Sectional expenses .......... 500.00

Committee expense .......... (300.00)

Budget, etc. ........... 100.00

Encyclopaedia of Sports ..... 50.00

Other committees ......... I 150.00

Officers' expense ............ (300.00)

President ............. 75.00

Secretary ............ 150.00

Treasurer............. 75.00

Total ..............\$1900.00

Unallocated balance ........ \$I I 57.69

The Secretary was authorized to ask each chairman for an estimate of his section needs for 1942 and to pass this information on to the President.

Instead of asking all of the committee chairmen to estimate budget needs for the year, it was

voted that the President should continue to approve for payment by the

Treasurer the usual expenses incurred in committee activities.

Chairman Samuel W. McAllister of the Committee on Constitution and By-Laws reported on possible methods of establishing connective tissue between the A.C.R.L. Board of Directors and A.C.R.L. Representatives on the A.L.A. Council. The board recommended, without vote, that this committee consider the possibility of making third and fourth year councilors ex officio members of the A.C.R.L. Board of Directors. If this appears possible, the committee is authorized to recommend the necessary constitutional revisions.

On December 28, I940, the A.C.R.L. Board of Directors voted "to admit to A.C.R.L. American Library Association life members joining prior to 1939 and institutional members without charge or allotment in 1941." It was

VOTED to continue this decision until such time as further action may be taken by the A.C.R.L. Board of Directors.

It was

VOTED that the general session program of a subcommittee to the A.L.A. Committee on Library Revenues be ratified.

After brief discussion, it was voted to discontinue (a) the Special Committee to Cooperate with the Commission of Junior College Terminal Education; and (b) the Committee on Departmental Libraries and Library Service to Departments of Colleges and Universities.

The President presented to the board the prospect of a petition from the Engineering School Librarians for section status in A.C.R.L. It was

VOTED that the Secretary attend the meeting of this group on Tuesday, December 30, and renew the division's earlier invitation to join the A.C.R.L. division.

At the request of President Coney, it was VOTED that the general session program of the Milwaukee meeting be arranged by the general directors of A.C.R.L.: Etheldred Abbot, Willard Lewis, and Winifred Ver Nooy.

Upon motion, the meeting adjourned at I I :40 P.M.

Benjamin E. Powell Secretary, A.C.R.L. 
A.C.R.L. Budget, 1942, APproved by Board of Directors, December 28, 194 I.

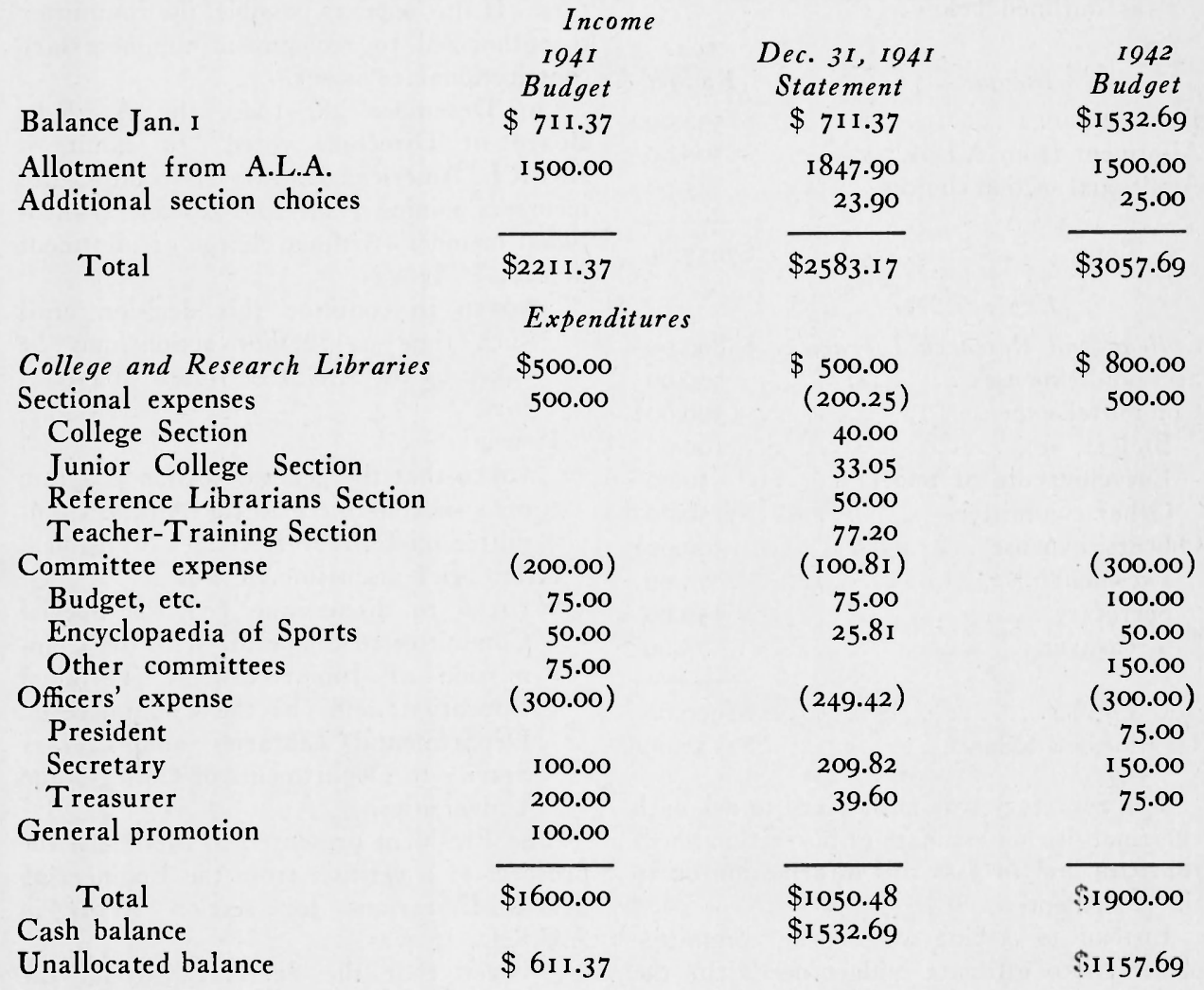

\section{A.C.R.L. Nominating Committee 1942-43}

(For Nominations for 1943-44)

Blanche Prichard McCrum, chairman, brary, Columbia, Mo.

Wellesley College Library, Wellesley, Charles F. McCombs, Main Reading Mass.

Mary Floyd, Eastern Kentucky State

Teachers College Library, Richmond

B. Lamar Johnson, Stephens College Li- versity Library, Bloomington 